\title{
Consultants for College and University Library Building Planning
}

By RALPH E. ELLSWORTH

$\mathrm{D}$

URING THE YeARS just before World War II, there was no college and university librarian alive who could, today, qualify as a building consultant in the college and university field. There were a few who had been through one building experience, but none who had been through a sufficient number to build up cumulative experience. Indeed, from the time the Bibliotheque Saint Genevieve Library was built in the middle of the nineteenth century until after World War II, it was rather generally accepted, in colleges and universities at least, that architects planned libraries without much help from librarians. There were exceptions: Theodore Koch at Northwestern, Louis R. Wilson at North Carolina, and Edna Hanley at Agnes Scott, for example. Joseph Wheeler and Alfred Githens had, of course, done outstanding work in the public library field, but there was no one in the college and university field of their stature and experience.

It was not until after 1940 in ALA that anyone realized the need for specialized planning for college and university libraries. Prior to that time the ALA Building Committee included representatives from all types of libraries-on the assumption (which ALA seems to be drifting back into) that a library is a library. Indeed it was only after strenuous objections were raised by A. F. Kuhlman, William H. Jesse, and myself that ACRL established its own separate committee. To be sure, there are certain heating, ventilation, and lighting problems that are common to all libraries, but that is about as far as the "Togetherness" theory applies.
Dr. Ellsworth is Director of Libraries, University of Colorado.

It was the Cooperative Committee on Library Building Plans that firmly established the idea of using building consultants. Today, practically all projects have used consultants.

Who is a building consultant? Unfortunately, it is anyone who thinks he knows how to plan buildings and can persuade an institution to hire him! There are no qualifying examinations to pass, no boards to be interviewed by, no criteria to meet. If one may judge them by the results, one must admit that consultants can get away with bad, sloppy work with no one the wiser. There is no organized follow-up work by any individual or organization. Here, perhaps, is a service ACRL could perform.

Officials at ALA nominate, upon request, consultants on the best information they have, but frequently this means nothing more than that they know the individuals and have a general idea of their competence. Yet, I have seen lists that nominate men I would not trust to design a dog house.

Seldom is a building failure labeled as such. For example, in one of the newest college buildings in the Midwest I found more planning mistakes than I have seen in recent years. Yet the man who served as consultant for that building has a good reputation as a consultant. How come? Could it be that librarians can't distinguish between a good and bad building? Or could it be that consultants are sometimes ignored?

In this article I shall attempt to state 
what a consultant is supposed to do, how he works, how he should be selected and paid, and how his work should be evaluated.

First, it should be understood that a consultant never finds the needs of any two problems to be alike. Sometimes the consultant is needed to sell the need for a new building to the trustees; sometimes it is to get faculty thinking channeled along certain lines; sometimes his primary task is to reason with a dean who for one reason or another has picked up an unworkable but fascinating conception of a library; and sometimes his job is to fill in for the librarian who may be incompetent, ornery, uninterested, or otherwise a problem.

I know of one instance in which the consultant made his big contribution at a cocktail party by persuading one of the college officials that the building should be turned ninety degrees. He earned his fee on that act alone because this change opened up the solution to many other problems that had blocked the planning.

Each new library consultation is a new challenge. After having worked on more than twenty assignments I have yet to find any two that come close to being alike. From this one may conclude, correctly, that the first thing a consultant does on a new assignment is to find out why his services have been requested. This may or may not coincide with what was told him in his correspondence with the officials. He will, after a time, develop special skill at getting at the heart of the problem and at finding out what's going on and who's in control. The normal situation, however, is that the institution has decided it needs a library building, has hired an architect, and wants to know what to do next.

How shall an institution pick the right consultant? Perhaps the safest way is to inquire of some six or eight librarians in charge of the kind and size of library involved. After obtaining, in this manner, a consensus on two or three con- sultants, one should ask each of them for (1) a list of the buildings for which he has served as consultant; (2) copies of these building programs for which the individual was responsible (under no circumstances should one choose a consultant who has done fewer than three buildings, either alone or with a colleague); and (3), a statement on what projects the consultant is already working.

Representatives should then be sent to inspect these buildings and to discuss with the librarian-if he or she was in charge at the time the building was planned (the problem of how to evaluate the comments of a second generation librarian is a baffling one, partly because this librarian won't know what the consultant did and partly because one of the generally present but less admirable traits of present-day head librarians is their habit of blaming the past for mistakes that usually stem from their own weaknesses) - the contribution made by the librarian.

At this point one must consider the question of how much blame can be placed on the consultant for mistakes that were made in planning. Or, to put the question another way, should a consultant stay with a project all the way, keeping mistakes to a minimum, when things are not going right, or is there a point at which it would be better for the institution concerned if he would resign and publicly disassociate himself from the project? How far should a consultant go in refusing to let a client have things in a building he knows to be wrong?

If the problem appears to be one of choice between several workable plans or ideas, the client's choice should always be respected. But if the consultant knows (and if he doesn't know enough to judge he shouldn't be a consultant) the client's or architect's decision will result in a building that is unworkable or full of major defects, or that will in a few years be a handicap to the institution, he 
should so inform the client in writing and, if necessary, withdraw from the project and state publicly why he has done so, unless by so doing he would be harming the institution unnecessarily or unwisely.

It can be argued that it's the consultant's job to give the client what he wants even if what he wants is wrong. A better case can be made for the position that the consultant should stay with the project to the bitter end, saving as much as possible out of the situation. One should remember that a building lasts a long time and that basic faults, if present, will last an equal length of time.

As to fees, the first question is why pay a consultant? Why not bring your plans to ALA and have some expert tell you what to do, free and no questions asked? This is done, and for minor problems it is not a bad idea.

But this has nothing to do with planning. Each college or university is different from all others. It has its unique geography, traditions, character, pocketbook, and desires. These must be carefully isolated, analyzed, and synthesized before one can develop a library plan. This cannot be done around the ALA convention halls. Furthermore, people will respect and use the things they pay for and disregard the things that are free. And if the payment is large enough to cause a little self-sacrifice, the advice given will be taken just that much more seriously. We have all seen some of our colleagues who came to the ALA with their building plans and go from one "expert" to another, like bees sucking honey from flowers, asking advice from all and then going home and taking advice from none, or possibly assembling a hodge-podge of unharmonious elements.

A library building is a complicated machine that will work only when all its elements are designed to fit the whole. It is not likely that more than one or two people can maintain a sense of the whole while the plans are being developed.
There is a place, of course, for group criticism, but this does not come in the creative stage of planning.

Fees vary from consultant to consultant according to the needs of the job and the amount of experience the consultant has had. One learns, with experience, how to work fast and to avoid typical errors. One hundred and fifty dollars a day, plus expenses, is a standard fee for an experienced consultant for ordinary, uncomplicated program writing and blueprint reading. A wise consultant will put in his contract a statement saying that if extraordinary situations arise (such as trouble with the architect) that call for more than ordinary service, he will so notify the client in advance and will ask for extra compensation of a specific amount. The fee will vary, too, depending on how much supervision is wanted.

The amount of time a consultant spends on a typical (if there is such a thing) college problem would be somewhat as follows: a preliminary visit of three days to study the local problem and to work out the first draft of a program; a second visit of one day with the architect on the site problem in relation to the program; and another two days on the final draft of the program. After the architect has developed plans there will usually be a series of one-day meetings to discuss the plans. (I am talking about a college library problem-a university problem usually requires three times as much time.) From this point on the consultant should check all blueprints against departmental requests for the local needs; he may or may not be asked to choose furniture and equipment; and he may or may not do floor layout. A college planning a $\$ 1,500,000$ building should budget $\$ 1,500$ for the consultant. He may use much less.

The question arises about the use of a single consultant or an organization of consultants such as Library Building Building Consultants, Inc. If the choice 
is between a relatively inexperienced consultant and an organization group, the latter should be chosen. The virtue of the group consulting service is that it makes fewer errors because more than one person works on the problem. The limitation of the group is that it is no better than the individuals who make up the group. The problem is comparable to that of choosing an architect. You may get better results from an individual architect who has the particular kind of ability and time your job requires. On the other hand, a larger firm that can run your problem through its highly specialized departments-programming, design, layout, construction, landscaping, equipment, etc.-may be better for your job. Some architects work better as individuals and some work better as members of a team. So it is with consultants. If an individual is chosen, it is most important that the owner satisfy himself on the quality of work the individual has done.

A good consultant-individual or group-will save the client a great deal of money, and, of even more importance, he will see to it that the building will do the work the client expects it to do.

The first task of the consultant is to help the institution prepare a written program - a document that will include answers to all the questions the owner, the donor (or the taxpayer), the architect, and the future users of the library could possibly ask.

The program should begin by asking the question of why a new building is necessary. Here the consultant should help the college or university think through a campus-wide system of reading resources or facilities, taking into consideration all the possible developments in micropublishing, mechanization of bibliographic searching, audio-visual devices, paperback books. Such questions as these should be raised: Are there to be departmental libraries, study hall facilities in academic buildings? In dormi- tories? What is the geography of the campus? What are the lines and flows of student movements?

Next comes the question of site. It has been my experience that there is usually one best site that can be spotted quickly, but that, for one reason or another (and these reasons frequently seem quite inconsequential to an outsider) the library can not be put there. And so one must hunt for the second best site.

Fortunately, on most college campuses distances are so short that the site is not a matter of great importance. But in a large university the problem is almost always critical. Unfortunately, none of us knows enough about the elements that should determine a library's location to be very certain of our advice. I am, for example, coming more and more to the conclusion that the single most important element is whether or not the faculty members who should use the library find the site easy and convenient. If they don't, they will, in one way or another, find ways of avoiding the library and they will not see to it that their students use the library as much as they would if the faculty were happy about the situation-even though all other elements are optimum.

The consultant will need to know how to find out which departments or colleges will use the library and where the center of gravity of this use will be; he will need to find the confluence of student traffic; he will need to study the campus master plan-where growth is to take place and to what extent; and he will need to be certain that the site plan is large enough to permit expansion and that it can be committed to library use.

Next comes the question of what kind of a building the institution wants. What is to be its mood, its style, and its symbolic place on the campus? What is the intellectual climate of the campus? The prestige of reading? The degree of reading sophistication of the students? The balance between teaching and research 
in the faculty? The relation between the library and the student union on the facilities for browsing should be determined if possible.

Having determined these background facts, the main part of the program should be written. This will be a description, considering proper relationships, of the various parts of the building with an estimation of the quantities required for each part. This will begin with an analysis, based on data supplied by the institutions, of the seating capacity derived, as well as the number of books that are to be housed, now and in the future.

In doing this the consultant should not forget that he is not an architect and that he should not try to design a building. Rather, he should try to tell the architect everything he should know so that he will know "what the function is the form must follow," if I may twist Louis Sullivan's dictum around. The consultant should stay out of the architect's way as long as the architect is expressing the program faithfully. Too often in the past, we librarians have blamed architects for mistakes that really are the result of faulty programming, not of architectural ineptitude.

Consultants should realize that today architects are striving mightily to create new styles that will be richer than the so-called "International" boxes we have had since World War II. Let us hope they will be able to do better than merely cover up a barren structure with a stone-like lattice of cement or iron. (And by this I am not referring to the New Orleans Public Library, where the use of iron lattice work had a local raison d'etre.) Surely we need not lose all we have gained the last twenty years in our concept of organic architecture.

Each part of the building should be described clearly in terms of its purpose, operations, special needs, and its spatial relations to other parts.

The consultant, in writing this part of the program, will try to follow the insti- tution's wishes and ideas if it has any, but more frequently he will be expected to tell the institutions about the best of the new ideas to be found in the newer libraries. He must be careful not to ride his own hobbies, or to impose concepts that would limit the freedom of choice in the future for the institution. If there is someone in the institution who wants to, and is capable of writing the program, by all means let him do it. The consultant's sole responsibility is to see to it that the program is written completely and accurately.

At this point a word on copying or borrowing ideas from other libraries is in order. It is my opinion that so many mistakes have been made in so many buildings that when we can find something done properly we should repeat the success-if it is relevant-and not worry about the repetition. We need not worry about the monotony for the simple reason that there are too few good examples to follow.

The style and arrangements of a good program need not be standardized. I offer as a model the program for Colorado College, written by Dr. Ellsworth Mason, librarian:

I. The Nature of the College

II. General Description of the Library

III. Specifications of the Library Area

Introduction to the Library:

1. Vestibule

2. Lobby and control

3. Circulation: Desk

Office

4. Reference

5. Periodical indexes

6. Periodicals

7. Card catalog

8. Reference office

9. New book browsing 
Technical Processes and Administration:

10. Receiving and shipping

11. Technical processes:

Order department

Cataloging and mending

Serials

Documents

12. Librarian

13. Librarian's secretary

\section{Books and Readers:}

14. Bookstacks and reading areas:

Stacks

Readers

15. Special collections

16. Bibliography

17. Microcard room

18. Listening area

19. Locked faculty studies

20. Student conference rooms

\section{Miscellaneous:}

21. Seminar rooms

22. Lock section

23. Staff room

24. Staff toilet and washroom
25. Smoking rooms:

Studies

Lounges

26. Typing rooms

27. Supply room

28. Toilets and washrooms

29. Elevator

30. Book return slot

31. Photo dark room

32. Reshelving stations

33. Student telephone

34. Fire exit

Summary of space requirements

If a consultant can be successful in developing a good program, the major part of his work is accomplished. Architectural competence is so high these days that one can be fairly safe in assuming that a good program will be well expressed. The consultant will, of course, follow each stage of the project through to completion and, if all goes well, he may occupy a seat in the back row at the library dedication and he will share in the pleasure of seeing a job well done.

\section{Miss Winchell Honored}

The Isadore Gilbert Mudge Citation for 1960 for Distinguished Contributions to Reference Librarianship was awarded to Constance Mabel Winchell, reference librarian at Columbia University, at the Montreal meeting of ALA's Reference Services Division, June 22. The citation was established by RSD in 1958 in honor of the late Isadore Gilbert Mudge, long reference librarian at Columbia.

Miss Winchell's citation reads in part:

For her constructive service to the library of Columbia University in building its reference collection ... . her trail-blazing book, Locating Books for Interlibrary Loan . . . her close personal identification with this award, as she was trained by Isadore Gilbert Mudge and has with distinction carried forward Miss Mudge's ideals and practices as reference librarian and has, through her assistance to Miss Mudge and later through her own frequent supplements and a new and completely revised edition, given increased value to that bible of the librarian, $A$ Guide to Reference Books.

Miss Winchell is a graduate of the University of Michigan and of Columbia. She joined the reference staff of the Columbia University Libraries in 1925 and has been reference librarian since the retirement of Miss Mudge in 1941. She is the second recipient of RSD's Mudge Award. Her regular contributions to CRL (one of which appears in this issue) supplement and keep up-to-date her famous Guide. 